\title{
High Density Polyethylene (HDPE) Vessel of Pompong as a Fishing Vessel for Bengkalis Fisherman
}

\author{
Siswandi $\mathrm{B}^{1}$ and Wasis Dwi Aryawan ${ }^{1}$
}

\begin{abstract}
Generally vessels of pompong are made from wood. In this era, wood for shipbuilding is difficult to obtain. So, it is necessary to find an alternative material as a substitute for wood. High density polyethylene (HDPE) can be used as of material for shipbuilding because it has advantages such as heat resistant, corrosion resistant and has a long durability. Size vessels with a length of $(L)=8.8$ meters, breadth $(B)=1.56$ meters, height $(H)=1.05$ meters and draft $(T)=0.6$ meters which makes the design shape of the vessel of pompong HDPE plastic. The vessel of the pompong plastic has a stability of $G Z$ value of 0.381 meters on the heel of 60 degrees and has a resistance of 0.74 kilonewtons at a speed of 5 knots.
\end{abstract}

Keywords-Vessel of Pompong, High density polyethylene, Stability, Ship Resistance.

\section{INTRODUCTION}

Bengkalis is one of the districts in Riau Province, Indonesia. Most of the coastal Bengkalis communities depend their life at sea to catch fish and survive. The prior function of the vessel pompong for local fisherman is to catch fish. Pompong vessel is a small boat made from wooden material, however, nowadays wooden materials for shipbuilding pompong is difficult to obtain. Meaning that there needs to be a new discovery of materials that could be used for shipbuilding as an alternative substitution of wood material. Plastic high density polyethylene (HDPE) can be used as an alternative material for shipbuilding as HDPE has advantages such as resistance to heat, anti-corrosion, flexible and resistant to aging.

A. Fishing vessel of pompong

Pompong vessel is a term used for vessels with a small size by driving machine contained in the hull. The fishing vessel of pompong forms as shown in Figure 1.

Vessel pompong is a coastal transportation which is used to meet basic needs and means of transportation between islands. The name of this small boat "Pompong" is a term used by the local people of Riau province.

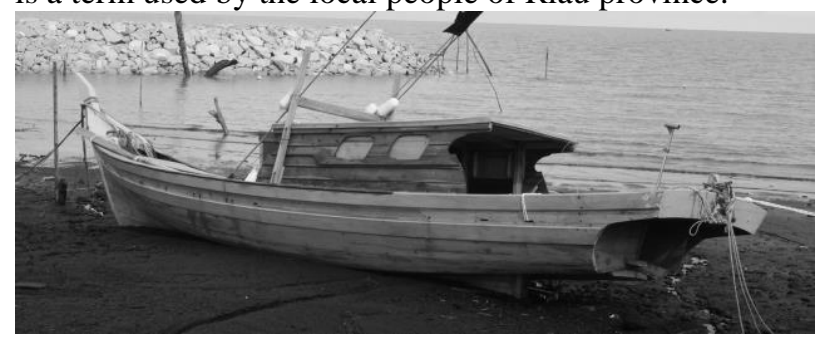

Figure. 1. Fishing vessel of pompon

\section{B. Plastic of HDPE (HighDensityPolyethylene)}

HDPE (high density polyethylene) is a material commonly used for household appliances such as milk bottles, tupperware, gallons of drinking water, folding chairs, and others. HDPE is a plastic material that is safe to use because of its ability to prevent chemical reactions between the plastic packaging made of HDPE with food or beverages that it is packed.

Apart from that, HDPE has the properties of a stronger material, blurred and more resistant to high temperatures. High density polyethylene (HDPE) is a polyethylene thermoplastic made from petroleum. This requires 1.75 $\mathrm{kg}$ of petroleum (as energy and raw materials) to make 1 $\mathrm{kg}$ of HDPE. It can be recycled, and has the number 2 in the recycling symbol. HDPE base material shaped like grains as shown in Figure 2.

HDPE has a tensile strength and a high intermolecular forces, it is also harder and can survive in high temperatures $\left(120{ }^{0} \mathrm{C}\right)$. For a more in-depth understanding about the strengths of HDPE material, refer to Table 1.

\section{Ship of HDPE}

Currently, ships with HDPE material is already widely in production by foreign nations such as Turkey, which is one of the boat making nations that uses entirely

HDPE material. Innovative products for building boats made entirely of plastic (HDPE) has been made over the last five years. One of the vessels made of HDPE plastic material can be seen as shown in Figure 3.

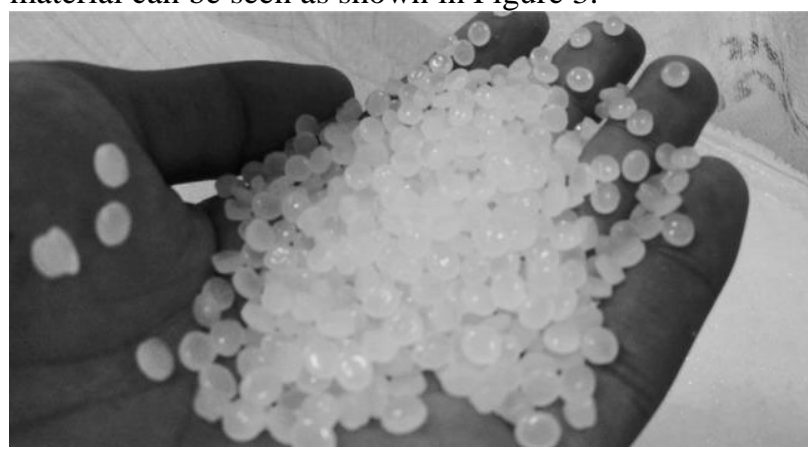

Figure 2. Grains of plastic HDPE

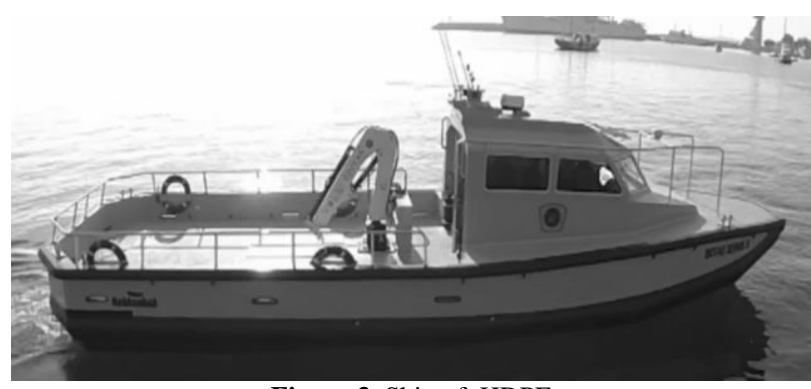

Figure 3. Ship of HDPE

${ }^{1}$ Siswandi B and Wasis Dwi Aryawan are with Department of Naval Architecture and Shipbuilding Engineering, Institut Teknologi Sepuluh Nopember, Surabaya, 60111, Indonesia. E-mail: siswandi.b86@gmail.com; wasis@na.its.ac.id. 
Advantages of HDPE material in manufacturing boats a. The extent of the area under the curve of GZ on a roll are: angle of $0^{\circ}-30^{\circ}$ should not be less than or equal to

- HDPE is highly durable against aging and corrosion 0.055 m.rad.

material (minimum last 50 years), the durability of b. The extent of the area under the curve of GZ on a roll HDPE boats are longer than other boats made of angle of $0^{\circ}-40^{\circ}$ should not be less than or equal to other materials. 0.090 m.rad.

- Durability rift good meaning it has little damage.

- HDPE is flexible and durable, resistant to the worst weather conditions.

c. The extent of the area under the curve of GZ at an angle of roll $30^{\circ}-40^{\circ}$ should not be less than or equal to 0.030 m.rad.

- It is easier to assemble than the HDPE material 2. IS Code 2008 compared to steel, wood, aluminum or other The maximum GZ value that occurs at an angle of $30^{\circ}$ composite materials. $180^{\circ}$ can not be less than or equal to 0.2 meters.

- Polyethylene has the advantage of anti-corrosion.

3. Section A.749

(18),

Chapter

3.1.2.3

- Non-toxic and easy to clean.

- Vessel HDPE does not need paint or any treatments. Angle at maximum GZ value should not be less than or equal to $25^{\circ}$

- Resistant to ultra violets, stable, fire-resistant and low 4. Section $\quad$ A.749, Chapter

TABLE 1.

PROPERTIES MATERIAL OF HDPE PLASTIC

\begin{tabular}{|c|c|c|c|}
\hline Property & Properties of HDPE & Unit & Test Method \\
\hline Density & 0.946 to 0.972 & $\mathrm{~g} / \mathrm{cm}^{3}$ & ASTM D-792 \\
\hline Melt Mass Flow Rate & $\begin{array}{c}0.030 \text { to } 10\left(190^{\circ} \mathrm{C} / 2.16\right. \\
\mathrm{kg})\end{array}$ & $\mathrm{g} / 10 \mathrm{~min}$ & ISO 1133 \\
\hline Tensile Yield Stress & $\min 17$ & $\mathrm{~N} / \mathrm{mm}^{2}$ & ASTM D-638 \\
\hline Tensile Break Stress & $\min 14$ & $\mathrm{~N} / \mathrm{mm}^{2}$ & ASTM D-638 \\
\hline Ultimate Tensile Stress & $\min 24$ & $\mathrm{~N} / \mathrm{mm}^{2}$ & ASTM D-638 \\
\hline $\begin{array}{c}\text { Tensile Elongation at } \\
\text { Yield }\end{array}$ & 1.0 to 27 & $\%$ & ASTM D-638 \\
\hline $\begin{array}{c}\text { Tensile Elongation at } \\
\text { Break }\end{array}$ & 10 to 1500 & $\mathrm{\%}$ & ASTM D-638 \\
\hline Tensile Creep Modulus & $292($ After $1000 \mathrm{hrs})$ & $\mathrm{N} / \mathrm{mm}^{2}$ & ISO 899-1 \\
\hline Compressive Stress & 20 & $\mathrm{~N} / \mathrm{mm}^{2}$ & ASTM D-695 \\
\hline Shear Strength & 18 & $\mathrm{~N} / \mathrm{mm}^{2}$ & ASTM D-792 \\
\hline Flexural Strength & 70 & $\mathrm{~N} / \mathrm{mm}^{2}$ & ASTM D-790 \\
\hline Flexural Modulus & $\mathrm{N} / \mathrm{mm}^{2}$ & ASTM D-790 \\
\hline
\end{tabular}

maintenance cost

- $100 \%$ recyclable.

\section{METHOD}

\section{A. Design fishing vessel of pompong plastic HDPE}

Research conducted centrally located in Bengkalis area of Riau, with the capacity needed to fulfill the local fisherman's needs. Then, planning is done followed by the design and depiction of ships pompong made of HDPE. The depiction of the model pompong HDPE using maxsurf and Auto CAD software.

\section{B. Stability of the ship}

The stability of the ship is a vessel's ability to return to its original position due to waves or other external forces.

Generally, vessels must meet the standards of the safety of shipping (safety of life at sea) and passengers comfort on the stability of the ship. Stability criteria used is the International Maritime Organization (IMO). The criteria of the International Maritime Organization (IMO, 1977) was used for the fishing boats as follows:
GM initial value at an angle of $0^{\circ}$ can not be less than or equal to 0.35 meters.

Calculation of the stability of fishing vessels can be calculated using the equation according to the approach of "Huseyin and Abdi (1999)" as follows:

Symbol description:

$$
\begin{array}{ll}
\mathrm{L} & =\text { length overall } \\
\mathrm{B} & =\text { molded breadth } \\
\mathrm{T} & =\text { design draft }
\end{array}
$$

$\mathrm{BM}=$ transverse metacentric radius

$\mathrm{H} \quad$ = depth

$\mathrm{GM}=$ metacentric height

I = transverse inertia moment

$\mathrm{KB}=$ height center of buoyancy

$\nabla \quad=$ volume displacement

$\mathrm{C}_{\mathrm{WL}}=$ waterline area coefficient

$\mathrm{KG} \quad=$ vertical center of gravity

$\mathrm{Cb} \quad=$ block coefficient

Calculating the value of $\mathrm{KB}$ using the following equation:

$\frac{K B}{T}=0.585578 \times\left(\frac{C w l}{C b}\right)^{0.01725}$ 
Value of $\mathrm{C}_{\mathrm{WL}}$ can be calculated by the following equation:

$C_{W L}=0.9670599 \times C b^{0.52085}$

Calculating the value of BM using the following equation:

$$
B M=\frac{I}{\nabla}
$$

Where:

$I=0.075645 \times L \times B^{3} \times C_{W L}^{1.41753}$

Calculating the value of $\mathrm{KM}$ using the following equation:

$K M=K B+B M$

Calculates the value of $\mathrm{KG}$ can use the equation following approach:

$K G=-0.00642 \times L+0.2669 \times B+0.3509 \times D+$ $0.272 \times \frac{L}{\nabla^{1 / 3}}-0.45126 \times C b-0.3337 \times \frac{L}{\{L \times B \times D\}^{1,3}}+$

$0.5411 \times \frac{B}{D}-0.8347 \times \frac{D}{T}$

Then to calculate the value of GM by using the equation of the following:

$G M=K M-K G$

So that the value of GZ is:

For small angles up to 15 degrees

$G Z=G M \sin \theta$

For angles above 15 degrees

$G Z=\left(G M+\frac{1}{2} B M \tan ^{2} \theta\right) \sin \theta$

Evaluation of vessel stability HDPE plastic pompong performed by using software Hydromax.

C. Ship resistance

Ship resistance is the amount of resistance force that is received by the ship's hull at a certain speed. The resistance of fishing vessel according to the method of "Holtrop and Mennen (1982)" can be calculated using the following equation approach:

Symbol description:

$\nabla=$ Volume displacement $\left(\mathrm{m}^{3}\right)$

$\rho \quad=$ Density of sea water $\left(\right.$ ton $\left./ \mathrm{m}^{3}\right)$

$\mathrm{S} \quad=$ Wetted surface area $\left(\mathrm{m}^{2}\right)$

Vs $\quad=$ speed $($ knot $)$

Fn $\quad=$ Froude number

$\mathrm{Rn} \quad=$ Reynold number

$\mathrm{Cf} \quad=$ Coefficient friction

$\mathrm{Cb} \quad=$ block coefficient

$\mathrm{Cm} \quad=$ Midship coefficient

$\mathrm{C}_{\mathrm{WP}}=$ coefficient water plan $=0.18+0.86 \mathrm{Cp}$

$\mathrm{CA}=$ correlation factor $\quad=0.0006$

$\Delta \quad=$ Displacement (ton)

$\frac{\mathrm{R}_{\mathrm{R}}}{\Delta} \quad=$ Residual resistance $(\mathrm{kN})$

$\checkmark \quad=$ Viscosity kinematic sea water

$=1.18831 \times 10^{-6} \mathrm{~m}^{2} / \mathrm{sec}$
Calculating the wet surface area of the vessel (S) using the following equation approach:

$S=L(2 T+B) \sqrt{C_{m}}\left(0.4530+0.4425 C_{b}+\right.$

$\left.-0.2862 C_{m}-0.003467 \frac{B}{T}+0.3696 C_{W P}\right)$

The Value of Froude number (Fr) can be calculated by the following equation:

$F n=\frac{V s}{\sqrt{g . L}}$

The value of Reynold number $(\mathrm{Rn})$ can be calculated by following equation:

$R n=\frac{V_{s} \times L}{v}$

Calculating value of coefficient friction $(\mathrm{Cf})$ can be using equation:

$C f=\frac{0.075}{\log _{10} R_{n}}$

The calculation of the value of residual resistance can using the equation following approach:

$\frac{R_{R}}{\Delta}=C \times e^{m_{1} F_{n}^{d}+m_{2} \cos \left(\lambda F_{n}^{-2}\right)}$

The value of $C$ can be calculated by following equation:

$C=2223105\left(\frac{B}{L}\right)^{3.78613} \times\left(\frac{T}{B}\right)^{1.07961} \times\left(90-i_{E}\right)^{-1.37565}(15)$

Where:

$i_{E}=125.67 \frac{B}{L}-162.25 \times C_{P}^{2}+234.32 \times C_{P}^{3}+$ $0.155087 \times(L C B)^{3}$

The value $\mathrm{m}_{1}$ can be calculated by following equation: $m_{1}=0.0140407 \times \frac{L}{T}-1.75254 \times \frac{\nabla^{\frac{1}{3}}}{L}-4.79323 \frac{B}{L}-$ $8.07981 \times C_{P}+13.8673 \times C_{P}^{2}-6.984388 \times C_{P}^{3}$

The value $m_{2}$ can be calculated by following equation:

$m_{2}=-1.69385 \times C_{P}^{2} \times e^{\frac{-0.1}{F_{n}^{2}}}$

The value of $\lambda$ can be calculated by following equation: $\lambda=1.446 \times C_{P^{-}}-0.03 \times \frac{L}{B}$

and

$\mathrm{d}=-0.9$

So that the total resistance vessels

$R_{T}=\frac{1}{2} \times \rho \times S \times V^{2} \times\left(C_{F}+C_{A}\right)+\frac{R_{R}}{\Delta} \times \Delta$

Evaluation of resistance to fishing vessel of pompong HDPE plastic performed by using hullspeed software.

\section{RESULTS AND DISCUSSION}

A. Design of lines plan pompong HDPE plastic

The size of pompong HDPE plastic for Bengkalis which will be designed is as shown in Table 2. 
August $2^{\text {nd }}$ 2016, Postgraduate Program Institut Teknologi Sepuluh Nopember, Surabaya, Indonesia

TABLE 2.

PRINCIPAL DIMENSION VESSEL OF POMPONG HDPE PLASTIC

\begin{tabular}{lrl}
\multicolumn{1}{c}{ Item } & Value & \multicolumn{1}{c}{ Unit } \\
\hline Length (L) & 8.8 & $\mathrm{~m}$ \\
Breadth (B) & 1.56 & $\mathrm{~m}$ \\
Height (H) & 1.05 & $\mathrm{~m}$ \\
Draught (T) & 0.60 & $\mathrm{~m}$ \\
CB & 0.57 & \\
VS & 5 & knot \\
\hline \hline
\end{tabular}

Depiction lines plan performed using software maxsurf 13 , with a variety of considerations and thoughts about how to the production process of plastic boats is then formed, lines plan design and hull shape designed fishing vessel of pompong plastic HDPE reduce any curve in the hull. Production process of the vessel with plastic material must be use the mold, in which the molds are made of steel material. Therefore, the design of the model that is done should consider the process of making molds and also the process of printing. Shape design lines plan fishing vessels of pompong HDPE made as shown in Figure 4.
B. Design of general arrangement pompong HDPE plastic

From the design of the line plan has been done, this corresponds to the shape of the hull that is made into a drawing general arrangement plan fishing vessel of pompong HDPE plastic. Designing a general plan vessel is performed using Auto CAD software. From the line plan drawn in software maxsurf then exported to Auto CAD. In Auto CAD software it is then carried out the division of rooms needed and put the equipment and equipment that are on board in fishing vessel of pompong HDPE plastic. The design of general arrangement plan the fishing vessel of pompong HDPE plastic can be seen in Figure 5.

C. Stability fishing vessel of pompong HDPE plastic

Evaluation of the stability the vessel is performed using software hydromax. Evaluation of stability in hydromax is the first planning loadcase value where value is filled in the form of heavy load and the position where the center gravity of the items, which is used as an item on loadcase of that equipment and the weight of the vessel itself. Total weight contained in loadcase must be equal to the weight of the vessel displacement. Loadcase evaluation stability vessel of pompong HDPE plastic can be seen in Table 3 .

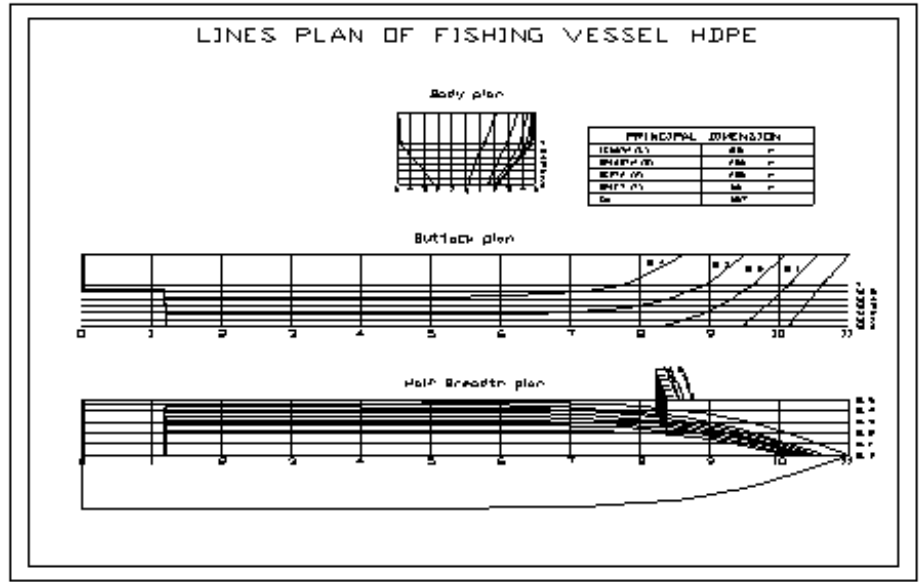

Figure 4. Design lines plan fishing vessel of pompong HDPE plastic

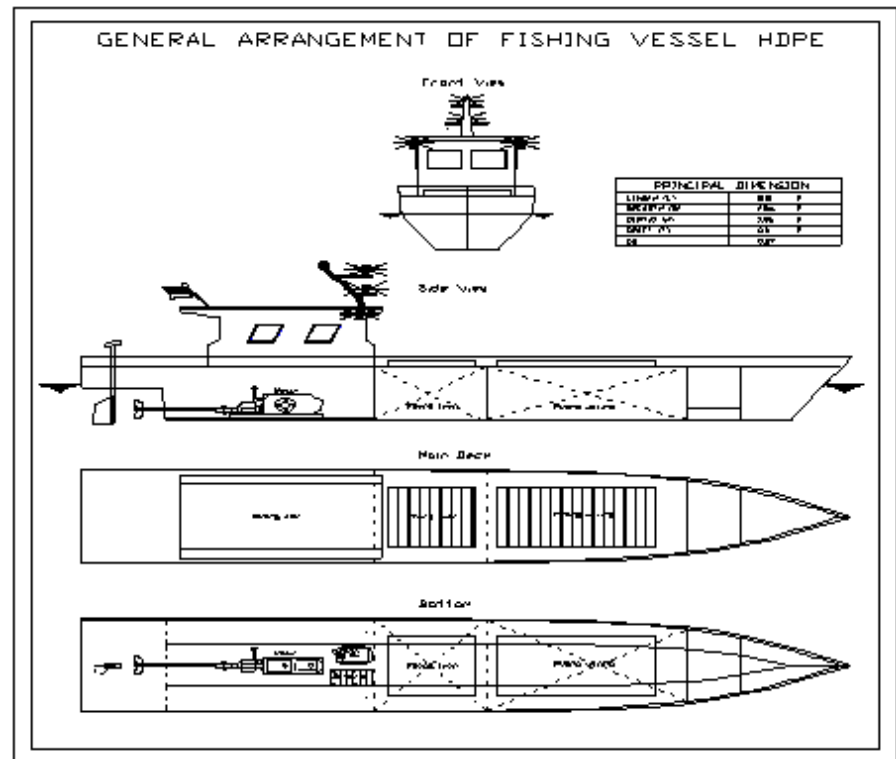

Figure 5. Design general arrangement fishing vessel of pompong HDPE plastic 
TABLE 3 .

LOADCASE OF POMPONG HDPE PLASTIC

\begin{tabular}{llccccc}
\hline \hline \multicolumn{1}{c}{ Item Name } & Quantity & $\begin{array}{c}\text { Unit Mass } \\
\text { tonne }\end{array}$ & $\begin{array}{c}\text { Total Mass } \\
\text { tonne }\end{array}$ & $\begin{array}{c}\text { Long.Arm } \\
\mathbf{m}\end{array}$ & $\begin{array}{c}\text { Trans.Ar } \\
\mathbf{m ~ m}\end{array}$ & $\begin{array}{c}\text { Vert.Arm } \\
\text { m }\end{array}$ \\
\hline Lightship & 1 & 1.873 & 1.873 & 4.200 & 0.000 & 0.140 \\
Main engine & 1 & 0.245 & 0.245 & 2.200 & 0.000 & 0.200 \\
Net & 1 & 1.300 & 1.300 & 5.000 & 0.000 & 0.300 \\
Fish & 1 & 0.600 & 0.600 & 3.750 & 0.000 & 0.300 \\
Box ice & 1 & 0.210 & 0.210 & 2.000 & 0.000 & 0.900 \\
Crew & 1 & 0.225 & 0.225 & 1.500 & 0.000 & 0.900 \\
Equipment & 1 & 0.154 & 0.154 & 2.500 & 0.000 & 0.900 \\
Total Loadcase & & & 4.607 & 3.972 & 0.000 & 0.306 \\
FS correction & & & & & & 0.000 \\
VCG fluid & & & & & & \\
\hline \hline
\end{tabular}

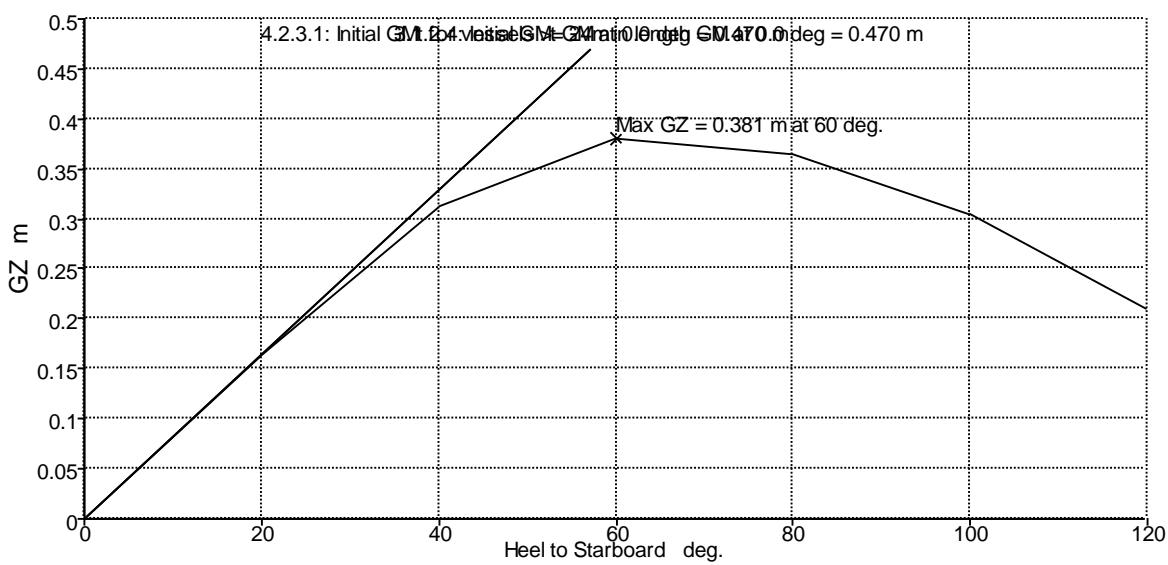

Figure 6. Curve stability fishing vessel of pompong HDPE plastic

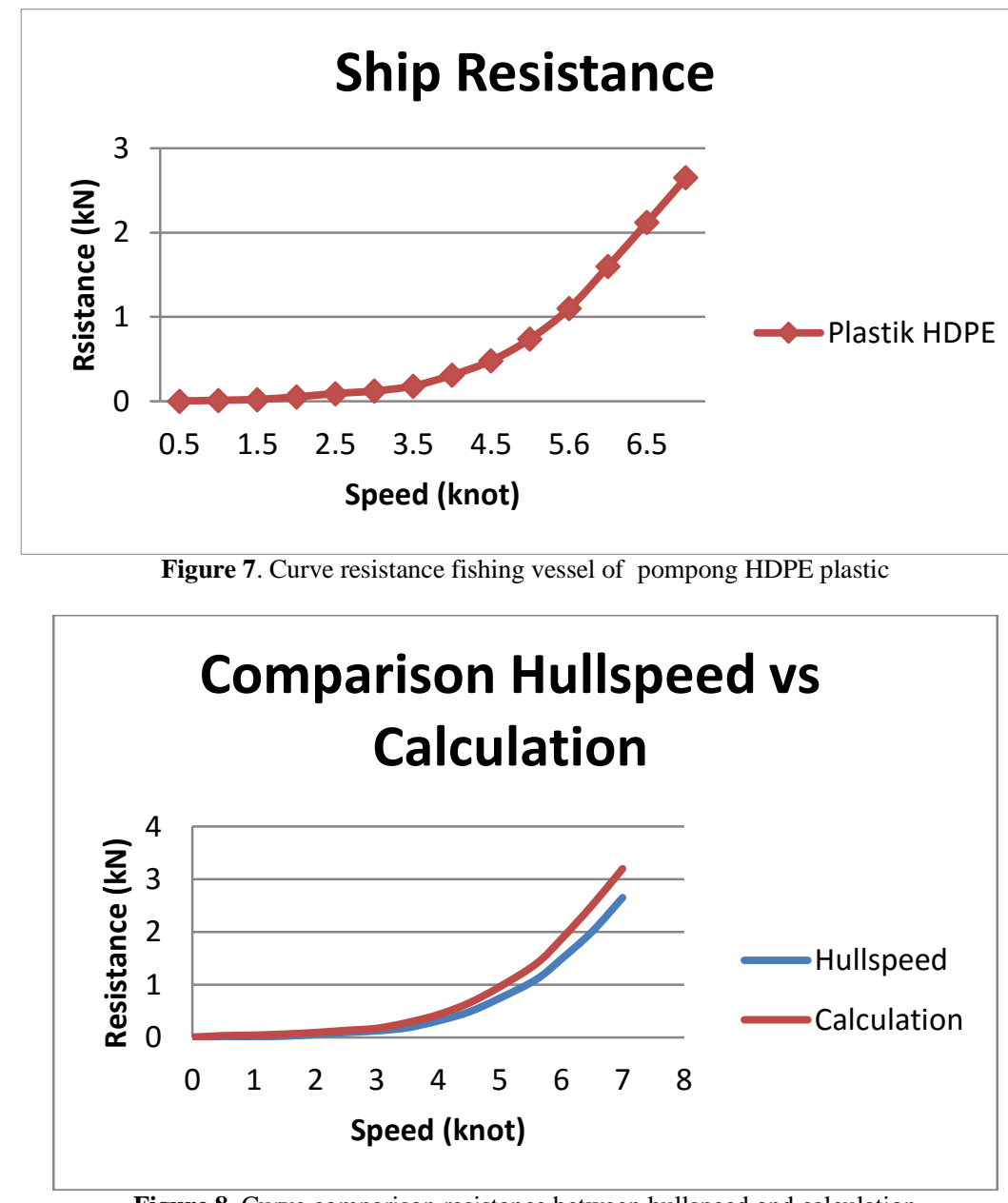

Figure 8. Curve comparison resistance between hullspeed and calculation 
Stability evaluation vessel of pompong HDPE results obtained GZ value at 0.381 meters at an angle $60^{\circ}$. Stability curve can be seen in Figure 6.

D. Resistance fishing vessel of pompong HDPE plastic.

Designing a ship can not be separated from the evaluation of hull resistance, where the evaluation is aimed to getting power required so that the vessel can operate in accordance with the desired speed. Evaluation of ship resistance is performed by using hullspeed software. The Speed fishing vessel of pompong is planned at 5 knots.

The evaluation results of the resistance to software hullspeed accordance with the method of Van oortmeersen where evaluation from 0 to 7 knots. For vessel of pompong HDPE plastic is planned at a speed of 5 knots. At a speed of 5 knots resistances that happened in the vessels is $0.74 \mathrm{kN}$. For more in-depth understanding of how the resistance vessels at each speed vessel of pompong HDPE plastic can be seen in Figure 7. Then the calculate by using the "van oortmeersen" method, the value of ship resistance HDPE pompong at a speed of 5 knots is $0.95 \mathrm{kN}$. Comparison of resistance between calculation by using van oortmeersen method and software hullspeed at each speed vessel of pompong HDPE plastic can be seen in Figure 8.

\section{CONCLUSION}

From the discussions conducted above there are a number of conclusions which include:

1) Material HDPE plastic as an alternative to wood in shipbuilding fishing vessel of pompong.

2) Plastic HDPE has properties harder, resistant to weathering and resistant to high temperatures.

3) The vessels made of HDPE plastic material has many advantages such as cheap maintenance and service life is longer.

4) The stability of the ship pompong HDPE plastic with $0.381 \mathrm{GZ}$ value at the angle of 60 degrees.

5) The ship resistance of pompong HDPE plastic by using software hullspeed at speed 5 knot is 0.74 kilonewton and the calculation value obtained of resistance by using van oortmeersen method at speed 5 knot is 0.95 kilonewton.

\section{ACKNOWLEDGEMENTS}

The author would like to thank for gratitude to the ministry of research technology and higher education of the republic Indonesia which funding the research under a scheme called Pra S2 - S2 saintek scholarships

\section{REFERENCES}

[1] Boatindonesia.Com (2014/03), Mengapa-Hdpe-BoatMempunyai-Prospek-Yang-Bagus,Diakses (27/09/2015), http://boatindonesia.com/2014/03/mengapa-hdpe-boatmempunyai-prospek-yang-bagus/.

[2] Holtrop, J. \& Mennen, G.G.J, "An approximate power prediction method", International Shipbuilding Progress 29 (335), 166170, Delft University, Netherland, 1982.

[3] Huseyin, and Kukner, A, "An approximate Method for Intact Stability of Fishing Vessel", Marine Technology, Vol. 36, No. 3 , pp. 171-174, 1999.

[4] International Maritime Organization, Food and Agriculture Organization of the United Nation (FAO), International Labour Office (ILO), Safety Recommendations for Decked Fishing Vessels of Less than 12 metres in Length and Undecked Fishing Vessels, Rome, Italy, 2012.
[5] Molland, A.F., Turnock, S.R., and Hudson, D.A, Ship Resistance and Propulsion, Cambridge University, New York, 2011.

[6] Oossanen, P.V, "Resistance Prediction of Small high-speed displacement vessel state of the art", Paper Presented at the symposium on The Impact of 200 Mile Economic Zone, Sydney, Australia, 1979. 